Portland State University

PDXScholar

1989

\title{
Sex role traits and psychological merger in lesbian relationships
}

Susan G. Dahlstrom

Portland State University

Follow this and additional works at: https://pdxscholar.library.pdx.edu/open_access_etds

Part of the Gender and Sexuality Commons, and the Psychology Commons Let us know how access to this document benefits you.

\section{Recommended Citation}

Dahlstrom, Susan G., "Sex role traits and psychological merger in lesbian relationships" (1989).

Dissertations and Theses. Paper 3869.

https://doi.org/10.15760/etd.5753

This Thesis is brought to you for free and open access. It has been accepted for inclusion in Dissertations and Theses by an authorized administrator of PDXScholar. Please contact us if we can make this document more accessible: pdxscholar@pdx.edu. 
AN ABSTRACT OF THE THESIS OF Susan G. Dahlstrom, for the Master of Science in Psychology presented June 23, 1989.

Title: Sex Role Traits and Psychological Merger in Lesbian Relationships.

APPROVED BY THE MEMBERS OF THE THESIS COMMITTEE:

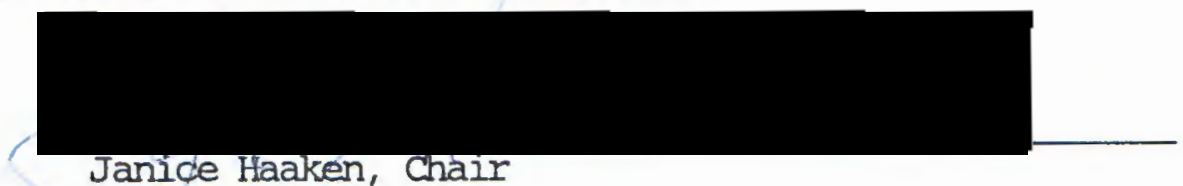
Janice Haaken, Chair

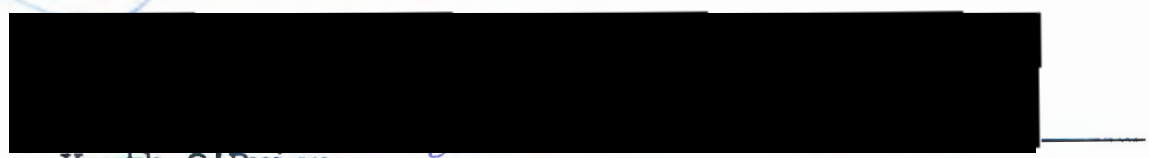

Kerth O'Brien

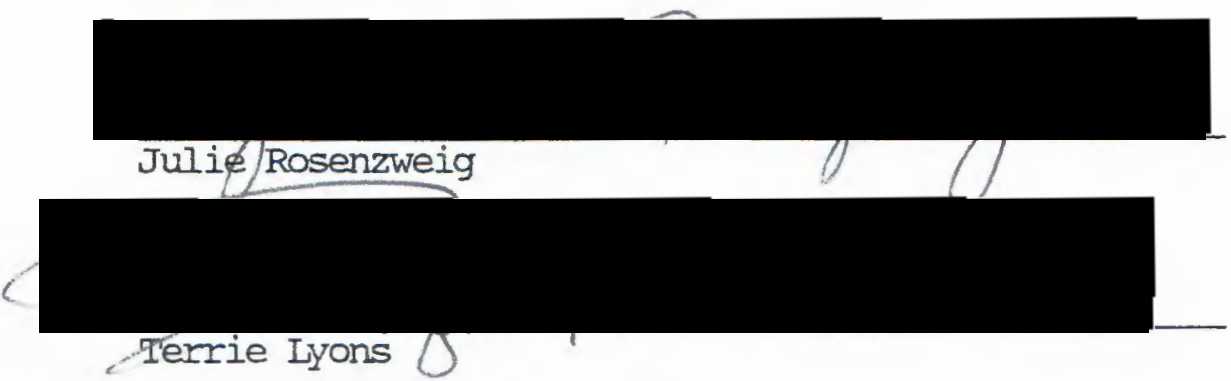

Much of the literature on lesbian relationships links the positive feminine relational trait (intimacy or communion) with problems of psychological merger (Burch, 1982, 1985; Decker, 1984; Elise, 1986; Krestan and Bepko, 1980). Karpel (1976), describes psychological merger as a person's "state of embeddedness in and undifferentiation within, the relational context" (p. 67). This study explores the femininity/masculinity sex role traits as they relate to psychological merger in lesbian couples.

Thirty-eight lesbian couples were recruited through friendship and acquaintance networks, newsletter announcements and direct 
solicitation of members of the Portland Lesbian Community Project (ICP). Couples had to have been living together in a primary relationship for one year or longer in order to qualify for the study. Each couple was mailed two questionnaire packets containing the Extended Personal Attributes Questionnaire (EPAQ) (Spence, Helmreich and Holahan, 1979), the Interpersonal Dependency Inventory and the Ego Identity Scale.

The tendency to psychological merger was operationally defined as ego diffusion and a high degree of interpersonal dependency. Dependency and Ego Identity scores were used as predictors of the tendency for an individual to become psychologically merged with her partner.

The Extended Personal Attributes Questionnaire supplied positive and negative femininity/masculinity trait scores (M+, F+, FC-, Fva-, M-) for each participant.

The masculine (M+) and feminine (F+) scales correspond to ideal positive masculine (agentic) and feminine (communal) traits. The masculine (M-) scale measured socially undesirable agentic traits (unmitigated agency). The two sets of undesirable feminine traits measured unitigated communion ( $\mathrm{FC}-$ ) and passive verbal aggressive (Fva) behaviors.

ANOVA analyses of the femininity/masculinity category scores was conducted to test the relationship of relative levels within each category (tertiles) to the tenaiency to psychological merger as measured by the constructs of dependency and ego identity. The results show that the positive feminine relational trait $(\mathrm{F}+)$ does not relate to the indicators of psychological merger while the negative feminine traits 
(FC-, FVa-), do relate to the indicators. Correlation analyses of the positive and negative trait scales show that the positive masculine $(\mathrm{M}+)$ category correlates negatively with the negative feminine communal (FC-) and negative feminine verbal aggressive (Fva-) traits. The positive feminine trait category $(\mathrm{F}+)$ is unrelated to levels of the negative feminine traits FC- and Fva-.

The results contradict the idea that psychological merger is related to the positive feminine relational trait $(\mathrm{F}+)$. This study indicates that it is the negative feminine traits FC- and Fva- which relate to the predictors of merger. Further, the lack of correlation between the positive and negative feminine traits allows one to see that these are independent constructs and not opposite ends of a feminine relational continuum. The significant negative correlation between the positive masculine $(M+)$ trait and the negative feminine traits FC- and Fva- indicates that merger tendency is related to low levels of the positive masculine (M+) agentic trait. Low levels of the agentic trait (M+) indicate a sense of powerlessness.

These results suggest that future research and reference to psychological merger in lesbian couples should shift from a focus on the purported harmful effects of too much intimacy $(\mathrm{F}+)$, to an emphasis on the effects of perceived powerlessness in one's enviroment. 
SEX ROLE TRAITS AND PSYCHOIOGICAL MERGER

IN LESBIAN REIATIONSHTPS

by

SUSAN G. DAHLSTROM

A thesis submitted in partial fulfillment of the requirements of the degree of

MASTER OF SCIENCE

IN

PSYCHOLOGY

Portland State University

1989 
TO THE OFFICE OF GRADUATE STUDIES:

The members of the committee approve the thesis of susan G. Dahlstrom presented June 23, 1989.
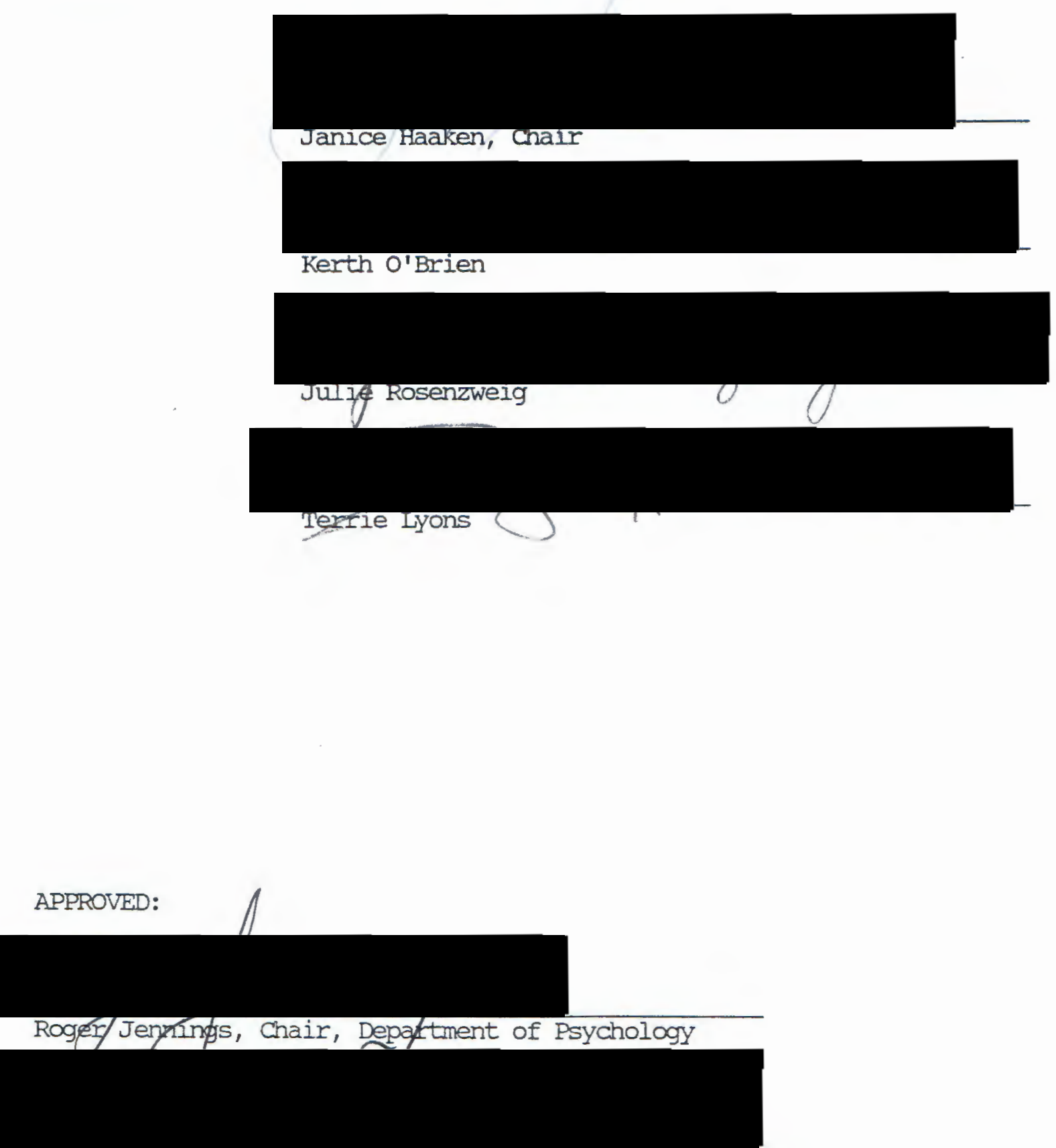

c. WIIllam Savery, Interim Vice Prgrost for Graduate Studies and Research 


\section{ACKNOWLEDGEMENTS}

I want to acknowledge three individual's contributions to this project. Dr. Janice Haaken for her invaluable expertise and guidance and Dr. Kerth O'Brien whose extensive knowledge and willingness to work long distance were essential to completing this task. Thank you both. The patience, help and occasional humor of my partner, Kim Murphy, made a difficult job mach easier. Thank you Kim, I love you.

Iastly, I want to thank the Lesbian community whose enthusiastic cooperation made this study possible. 
TABIE OF CONTENTS

PAGE

ACKNOWLEDGMENTS . . . . . . . . . . . . . . . $i$. .

IIST OF TABLES .................. . . . . vi

\section{CHAPIER}

I

INTRODUCTION . . . . . . . . . . . . . . . 1

Object Relations Theory. . . . . . . . . . 2

Female Development . . . . . . . . . . 4

Couples Research . . . . . . . . . . 7

Summary. . . . . . . . . . . . . 11

II METHOD ....................... 13

subjects . . . . . . . . . . . . 13

Instruments. . . . . . . . . . . . 14

Procedure. . . . . . . . . . . . 17

III $\quad$ RESULTS. . . . . . . . . . . . . . 19

Comparison of Subjects on Demographic and Background variables. . . . . . . . . . . . . . 19

Differences Among Sex Role Self-Concept Categories in Psychological Merger Tendencies. . . . . . . 21

Femininity/Masculinity Categories in Psychological

Merger Tendencies. . . . . . . . . . . 23

Distribution of Individuals by Sex Role Self-Concept Category .................. 26

Distribution of Partners within Couples by Sex Role Self-Concept Categories. . . . . . . . . . 26

Distribution of Partners by Negative Sex-Role Trait Tertiles................. 
Relationship Between Femininity/Masculinity Sex Role Trait Scores and the Indicators of Psychological

Merger: Dependency and Ego Identity. . . . . . 33

Relationship Between Positive and Negative

Femininity/Masculinity Scores. . . . . . . . 35

Distribution of Individuals and Partners by Sex Role Self-Concept Categories. . . . . . . . . .

Distribution of Partners by Negative Sex Role Trait Tertiles . . . . . . . . . . . . 38

Implications of This study . . . . . . . . 38

REFERENCES. . . . . . . . . . . . . . . . 44 APPENDICES
A NEWSLETTER ANNOUNCEMENT. . . . . . . . . 48
B BACKGROUND INFORMATION ............... 50
C EXIENDED PERSONAL ATTRTBUTES QUESTIONNAIRE (EPAQ) • . 54
D EGO IDENTTTY SCAIE (EIS) . . . . . . . . . 58
E INIERPERSONAL DEPENDENCY INVENTORY (IDI) ....... 61 
IIST OF TABLES

\section{TABLE}

PAGE

I Constructs of Interest Categorized by Dependent and Independent variables . . . . . . . . 20

II Mean Demographic Scores and Background Variables by Sample Subset and Sex Role Self-Concept Group . . .

III Mean Femininity/Masculinity (EPAQ) Scores by Sample subset. . . . . . . . . . . . . . .

IV Summary of Analysis of Variance on the IDI and EIS Scores comparing the Upper and Lower Tertiles of the Positive and Negative Feminine/Masculine (EPAQ)

scores. . . . . . . . . . . . . . .

$V \quad$ Distribution of Individuals By Sex Role Self-concept Categories. . . . . . . . . . . . . .

VI Distribution of Partners by Sex Role Self-Concept Categories. . . . . . . . . . . . . .

VII Distribution of Partners by Combined Sex Role Self-Concept Categories . . . . . . . . . . .

VIII Distribution of Partners by Negative Sex Role Trait

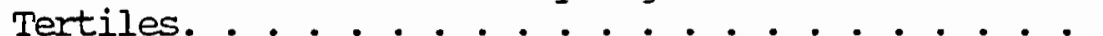

IX

Correlations Between Positive Sex Role Trait Scores and Negative Sex Role Trait Scores by Sample Subset . . . 
CHAPTER I

\section{INTRODUCTION}

Little empirical research exists concerning the dyadic issues of lesbian relationships. Most relationship studies have focused on heterosexuals; Homosexual research typically focuses on gay men, with the issues of etiology and personal adjustment to homosexuality most prominent (Morin, 1977). Clinicians who treat lesbians or lesbian couples have had little documented evidence about the nature of love relationships between women.

Much of the clinical literature on lesbian relationships that does exist focuses on the psychodynamic of merging, also referred to as fusion or enmeshment (Burch, 1982 \& 1985; Decker, 1984; Elise, 1986; Krestan and Bepko, 1980). These terms describe a relational context in which partners find it almost impossible to function autonomously from one another and fear that to do so would be a rejection of the partner. Karpel (1976), describes fusion (psychological merger) as a person's "state of embeddedness in and undifferentiation within, the relational context" (P. 67). Personal identity is obscured and the self is defined solely in relation to the other. Although conflicts about differentiation and autonomy are also found in heterosexual and gay couples (Blumstein and Schwartz, 1983) it is apparent, from the number of clinical descriptions of psychological merger as a problem in lesbian relationships, that merger conflicts occur "more frequently and 
with greater intensity in committed lesbian relationships" (Krestan and Bepko, 1980, P. 277) than in any other form of dyad.

\section{OBJECT REIATIONS THEORY}

The object relations school of psychology is the theoretical base from which the term merger (also described as fusion or enmeshment) is derived. Psychodynamic theorists such as Fairbairn (1952), Mahler (1974), Jacobson (1964), Kernberg (1976), Kohut (1977), and others have sought to explain human development in terms of people's relationships with others. The term 'object relations' refers to internal representations of people or parts of people which form the basis of relational capacities. Early developmental stages, according to object relations theorists, are "characterized by greater separation from mother, increasing sense of boundedness, self-control and self as origin of action" (Jordan, 1984, P. 1). Transient psychological merger with another is a normal part of all relationships, occurring "at moments of sexual and emotional intimacy" (Burch, 1982, P. 201). In adults, psychological merger with another becomes a pathological state when the individual loses his/her self/other boundary and hence her autonomy (Mahler, 1974) and the merger state becomes extended beyond the transient experience. This self/other fusion is considered to be a regression to the mother/infant symbiotic phase in which the infant cannot distinguish itself from its mother. In early object relations theory, the infant/mother symbiosis is considered to be a natural developmental stage for the infant and a pathological state for the acult. 
Early object relations theorists argue that the infant develops from a state of psychological merger with mother to a gradually more autonomous, separate self. Fairbairn (1952) describes this merger as a connection to mother which allows no thought of seeking connection to others, i.e. non-maternal objects. The maternal object constitutes the total focus of the infant's experience with her environment. Fairbairn contrasts merger with 'mature dependence', a term describing the healthy adult's ability to form interdependent attachments with others. "In maturity the dependency is conditional, with other objects always potentially available, as opposed to the unconditional dependence of the infant on his sole objects - the parents" (Greenberg \& Mitchell, 1983, P. 161).

Daniel Stern (1983) shares the psychoanalytic perspective which looks at early development as important to an understanding of the adult. In a recent contribution to object relations theory, stem offers a new perspective on the concept of psychological merger; Stern explores the preverbial infant's sense of self in order to conceptualize the development of normal interpersonal relations (Stern, 1983 P. 10). The early object relations theorists, with the exception of Mahler, learned of the infant from the clinical reconstructions of childhood which unfolded in the therapeutic relationship. Stern takes a much closer look at the infant by drawing on the traditional view of infant development, which he calls the "clinical infant", with the rich body of developmental research that has become available through direct observational studies of the infant. This infant he calls the "observed infant" (Stern, 1983 P. 4). The synthesis of the "clinical infant" material with the "observed infant" research has led Stern 
(1983) to conclude that, in contrast to the early theorists,

There is no symbiotic-like phase, in fact, the subjective experience of union with another can occur only after a sense of a core self and a core other exists. Union experiences are thus viewed as the successful result of actively organizing the experience of self-being-with-another, rather than as the product of a passive failure of the ability to differentiate self from other (P. 10).

Furthermore, Stern believes that the sense of self-with-other is a life span developmental task with infancy being a particularly sensitive period of development. Stern is offering a new paradigm for object relational development. Rather than moving from symbiosis to autonomy, as early object relations theorists posited, stern is suggesting that the infant develops from an autonomous state to a learned ability to form a 'union' with another, i.e. from autonomy to a capacity for symbiotic relationship.

FEMALE DEVELOFMENT

While Stern recognizes the potentially destructive aspects of merger, he also conceptualizes merger as a positive part of a life span developmental process (Stern, 1983). Stern's conceptual shift is also evident in recent theories of women's psychological development which are more validating of relationship than early theoretical models of development.

Recently, theories of women's psychological development advanced by Chodorow (1978), Gilligan (1982), and Dinnerstein (1977) attempt to explain how psychological merger can enhance rather than restrict individual growth. Feminist psychological theories challenge the traditional concepts of healthy mental development which have stressed 
that separateness is the key to psychological maturity (Kohut, 1977; Mahler, 1974).

Chodorow (1980), Gilligan (1982), and Dinnerstein (1977), in theorizing about the early stages of development, have argued that males and females have different experiences in relationship with the mother. "Mothers tend to identify more strongly with their girl babies. They do not seem to have as clear a sense of physical boundaries between themselves and their girl children as do mothers of boys" (Flax, 1978, P. 174). The daughter, being identified with mother, is maintained in a more prolonged and intense merger state with the mother than is the son. This extended period of close relationship with mother enhances her capacity for relationship while diminishing her sense of separate self. The son, on the other hand, develops a stronger sense of separateness when, as he becomes aware of himself as male, he must "establish himself continually as separate from his mother in order to be securely male" (Burch, 1985, P. 102).

There are also problems associated with the male identified pathway of development-separateness. The over-emphasis in development of the male's sense of power and separateness can result in narcissistic disorders. The narcissistic disordered person exhibits a persistent pattern of gradiosity, lack of empathy, and over-sensitivity to the assessment of others (American Psychiatric Association, 1987).

Early theorists have tended to overvalue the male developmental pathway and undervalue the female pathway portraying the male pathway of autonomy as synonymous with maturity. Separateness and relatedness have appeared to be bipolar traits with men predominant at one pole and women at another. However, studies by Raney (1976) and Raush (1977) 
reject the concept that intimacy (relatedness) and autonomy are polar opposites, an increase in autonomy necessitating a decrease in intimacy capacity. Autonomy and attachment on closer scrutiny appear to be "distinct and not mutually exclusive orientations" (Peplau, Cochran, Rook and Padesky, 1978, P. 25). These studies suggest that autonomy and intimacy are independent dimensions which allow an individual to be "strongly oriented towards both ideals". (Peplau et al., 1978, P. 25). Both males and females are thus deprived of potential wholeness by a polar concept of gender identity which reifies gender differences and treats those differences as inevitable and natural. The reification of gender differences loses the nuance and complexity of gendered experience. This does not negate the fact that men in our culture more often have a greater capacity for autonomy and women a greater capacity for intimacy (Peplau \& Cochran, 1982). The polar concept does, however, make gender identity problematic for those individuals who are developed in both traits or the 'wrong' gender trait (Riddle \& Sang, 1978; Alperson \& Friedman, 1983).

In our patriarchal culture, with maturity synonymous with autonomy, "the predominately female capacities for relatedness, emotional nurturance and nurturance are devalued" (Burch, 1985, P. 102-103). The daughter is raised to be nurturant, a devalued gender trait. She has an understandably ambivalent identification with mother as female, and she may in fact be expected to meet her own mother's neglected needs for relatedness (Caplan, 1981). She is identified with and taught to nurture by her mother but may in fact experience a deficit of nurturance in her own development (Flax, 1978). Although 
possessing an enhanced capacity for relatedness, she carries many conflicts about autonomy and dependency in relationship.

If we can abandon the notion that maturity and separateness are the same thing, then we can begin to see the potential in a relationship that enhances intimacy. "Such a relationship can help to assuage the early deprivations a woman may have suffered" (Burch, 1985, P. 104). Burch (1985) joins with Stern and Chodorow in arguing that the process of growth in relationship is not about separateness but about "finding one's self inside the merger and keeping one's self through the transition back out of it" (P. 107). The lifelong development of the self depends upon the back-and-forth process of merger and separation. "Merger is not destructive per se; only when a relationship is fixated in merger has the process gone awry" (Burch, 1985, P. 108).

\section{COUPLES RESEARCH}

The study of individuals in relationship (couples) can add empirical evidence to support or modify the existing theories of relational development. Recent clinical and developmental theory is showing a growing interest in and appreciation of relationship as a key factor in developmental process.

Too often, however, relational issues have been phrased in regressive terms such as merged, symbiotic or undifferentiated, suggesting that intense interpersonal connection involves a movement into more primitive functioning. If there is not appreciation for the development of more complex, differentiated patterns of connection and intimacy, then the relational aspect of self development will continue to be inadequately understood and devalued (Jordan, 1984, P. 2). 
Several studies examining relationship quality (Alperson \& Friedman, 1983; Kurdek \& Schmidt, 1986a, 1986b; Schullo \& Alperson, 1984; Spence, Helmreich \& Holahan, 1979) have explored the relationship between sex role self-concept and various aspects of relational functioning. Sex role self-concept is a measurement of an individual's perception of herself as masculine, feminine, undifferentiated (low masculine and low feminine), or androgynous (high masculine and high feminine) .

The use of the terms masculine and feminine are misleading in that they reinforce sex role stereotyping which portrays the male as primarily active and independent in the world and the female as primarily dependent and less capable than the male of affecting her enviroment. In order to support the idea that these stereotypic traits are, in fact, found in both sexes, this study will relate to the terms masculine and feminine as agency and communion traits in order to avoid reinforcement of sex role stereotypes. Schullo and Alperson (1984) introduced the terms agency and communion to replace the male/female terminology. These two basic properties, agency and communion, are characteristic of Iiving organisms (Bakan, 1966): "a sense of agency, manifested in such characteristics as self-assertion, self-protectiveness, and self aggrandizement, and a sense of communion, manifested in selflessness and a desire to be at one with others" (Spence, et al., 1979, P. 1673). The usefulness of the study of trait characteristics will be enhanced by disentangling these dimensions from stereotypic concepts of sex roles and masculinity and femininity.

Recent studies (Bem, 1974; Spence \& Helmreich, 1978; Spence, Helmreich \& Stapp, 1975) have suggested that 'masculine' agency 
characteristics and 'feminine' communion characteristics are separate, independently varying dimensions. Furthermore, they have proposed that both dimensions "contribute positively to effective functioning in members of both sexes" (Spence et al., 1978, P. 1674). The two personality instruments employed in these studies are the Personal Attributes Questionnaire (PAQ; Spence \& Helmreich, 1978) and the Bem Sex Role Inventory (BSRI; Bem, 1974). Both instruments contain separate Masculinity (M) scales and Femininity (F) scales; the M scale of the PAQ relating to socially desirable agentic traits and the $F$ scale relating to socially desirable communal traits. The normative data supports the concept that the sexes differ in the relative amount of agentic and communal characteristics, i.e. males are more agentic and females are more communal. However, a number of individuals are always found who score high on both $\mathrm{M}$ and $\mathrm{F}$ scales (androgynous) or low on both scales (undifferentiated).

Studies using both the $\mathrm{BEM}$ and $\mathrm{PAQ}$ instruments suggest that in both sexes androgymous and masculine (agency) scoring individuals are "higher in self-esteem and lower in anxiety, depression, and other indices of emotional distress" (Spence \& Helmreich, 1980, P. 149) than are feminine (communal) or undifferentiated individuals.

Relationship studies employing sex role self-concept instruments have reported that androgynous and feminine (communal) subjects have higher relationship quality and more consistency in interpersonal perception than masculine (agency) and undifferentiated subjects (Alperson \& Friedman, 1983; Kurdek \& Schmitt a, 1986; Schullo \& Alperson, 1984). Furthermore, studies comparing heterosexual, gay and lesbian couples have found that the androgynous (high agency and high 
communion) and feminine (high communion) trait categories to be the most salient to good relational functioning, regardless of sexual orientation. That is, the female or communion trait is the clear factor in relational capacity. Further, the Schullo and Alperson (1984) study suggests that,

The sex of the partner seems to be a critical variable in these analyses. The observation that in our culture women are trained to please others whereas men are trained to please themselves appear to be valid. consequently, the socialization of men and women prevails regardless of whether one is concerned with homosexual or heterosexual relationships (P. 998).

It appears, then, that the androgynous subjects are not only individually but also relationally a psychologically healthy trait group; and, the masculine group is higher in self-esteem or agentic strengths relative to the feminine group which is more adept at relational or communion functioning. Furthermore, sexual orientation has no affect on these results. Spence et al. (1979) have suggested that there are socially undesirable 'masculine' and 'feminine' characteristics to be found within the grouping of agentic and communal traits and that the consequence of these traits are harmful to those who possess them. Bakan's (1966) work is theoretically relevant to this idea. "He proposes that a strong sense of agency, unmitigated by a sense of commuion, is destructive to the individual and to society. Similarly, communion must be mitigated by agency if the individual is to function effectively" (Spence et al., 1978, PP. 1674\& 1675). The Extended Personality Attributes Questionnaire (EPAQ; Spence et al., 1979) was designed to include measurement of these negative agentic and communal traits; the FC- scale corresponding to unmitigated communion, 
the Fva- scale corresponding to vertal aggression and the M- scale corresponding to urmitigated agency.

The relationship literature, then, combined with the observed prevalence of psychological merger problems in lesbian relationships, suggests that the feminine communion trait, when joined in a relationship between two women, contributes to the possibility of problematic merger in the couple. Although much of the literature on lesbian relationship (Burch, 1982, 1985; Decker, 1984; Elise, 1986; Krestan and Bepko, 1980) allude to the communion trait as a major factor in lesbian psychological merger, there are no studies which examine that claim empirically.

\section{SUMMARY}

I have reviewed four literatures which explore the concept of psychological merger: the theoretical literature, recently challenged by Stern (1983), which has historically pathologized merger and idealized separateness; the clinical literature that explores the problematic aspects of merger in lesbian relationships; the feminist literature, which challenges the patriarchal viewpoint that overvalues separateness and undervalues relational capacity; and the couples research, an arena of empirical study that consistently yields data supporting the importance of the relational or communion trait to positive relationship functioning.

A joining of these literatures might lead one to view the communion trait as existing on a continuum; a certain amount of communion trait is psychologically and relationally healthy, however, too much resulting in pathology i.e., psychological merger. I believe that both 
the theoretical literature and the clinical literature on lesbians have tended to broadly link pathological psychological merger to the female capacity for relational strength; and that this has gone understandably unchallenged in a society that devalues the experiences of women.

Rather than embrace such a limited notion, I theorize that it is not conmunion per se, but unmitigated communion, a desire for communion without balancing agentic traits, that is most salient to problematic psychological merger. My study examines the contributions of positive and negative sex role traits to the tendency for psychological merger. In this study I focus on two questions:

1) do an individual's sex role traits relate to her tendency to psychological merger and

2) in couples, do specific combinations of sex role traits relate to the tendency for psychological merger?

I predict that the tendancy to psychological merger will be related to the negative feminine traits -- unmitigated communion and passive verbal aggression - and I further predict that merger will not be related to the positive feminine trait -- positive communion. 
CHAPIER II

METHOD

SUBJECIS

Subjects were 38 lesbian couples residing in the Portland, Oregon metropolitan area. To qualify for the study, each couple had to have been living together in a primary relationship for one year or longer.

The lesbian couples were recruited through friendship and acquaintance networks, newsletter announcements (see Appendix A) and direct solicitation of members of the Portland Lesbian Community Project (ICP). Ethical standards of the APA were followed in recruitment and treatment of participants. Table II provides background information for seven demographic variables: age, income, education, length of current relationship, number of previous relationships, presence of children in the household, and home ownership. In general, the subjects were well educated with a mean of one year of graduate school. The participants were economically stable with over $\$ 22,000$ income per person and $40 \%$ owning their homes. They had a mean age of 36 years and were stable in their relationships with current relationships averaging six years duration with a mean of less than two previous relationships. Individuals were predominantely white $(92 \%)$. Seventy percent reported either no religious beliefs or alternate, non-traditional, spirituality, i.e. womens', holistic, metaphysical, or inner spirituality. 


\section{INSTRUIMENTS}

The Extended Personal Attributes Questionnaire (EPAQ), (see Appendix C), developed by Spence, Helmreich and Holahan (1979) was chosen to supply the sex role trait information. The EPAQ is the only instrument related to sex roles that includes negative sex role stereotypes.

The EPAQ consists of five, eight item scales. The masculine (M+) the feminine $(\mathrm{F}+)$ and masculinity-femininity $(\mathrm{M}-\mathrm{F}+)$ scales correspond to the earlier PAQ scales. The development of the PAQ scales is described in spence \& Helmreich (1978). The negative masculine (M-) and feminine (F-) scales were developed by submitting the scale items to groups of male and female college students to rate the 'ideal' of each sex, the ideal member of each sex falling toward the pole indicating a relative absence of the negative trait. The masculine (M-) scale consists of eight traits "whose presence was (a) judged to be socially undesirable for members of both sexes, (b) attributed more frequently to males than to females and (c) agentic in content" (Spence et al., 1979, P. 1678). The feminine (F-) scale contains two sets of undesirable feminine traits. The first set consists of four items describing umitigated communion ( $\left.\mathrm{FC}^{-}\right)$. The second four items are descriptive of verbal passive-aggressiveness (Fva-). Agentic and communal content were determined by the investigators (Spence et al., 1979).

The masculine $(\mathrm{M}+)$ and feminine $(\mathrm{F}+)$ scales correspond to ideal positive masculine and feminine traits. The masculinity-femininity 
$(\mathrm{M}-\mathrm{F}+)$ scale is not relevant to this investigation and will not be further referred to in this study.

The negative and positive items are combined to form a 40 item questionnaire (EPAQ). Each item is accompanied by a 5-point scale and scored from $O$ to 4. The $\mathrm{M}+$ and $\mathrm{M}$ - scores are considered masculine (agentic) and the F-, Fva- and FC- scores are feminine (communal). A total for each scale is obtained by summing item scores.

The tendency to problematic psychological merger, defined as ego diffusion and a high degree of interpersonal dependency, will be determined by assessment of ego identity and interpersonal dependency.

The rationale behind the use of an ego-identity scale is in viewing ego identity in the Eriksonian sense (1950); that is, the healthy ego identified individual is able to function as a separate individual. Ego diffusion, being the opposite of ego-identity, is a state in which one loses a sense of separate self and has a lack of continuity of self over time (Erikson, 1959). The description of ego diffusion is similar to clinical descriptions of individuals experiencing problematic psychological merger - "state of embeddedness in and undifferentiation within, the relational context" (Karpel, 1976, P. 67). Ego diffusion as it applies to psychological merger is not as debilitating as psychotic or borderline conditions which also manifest problems with ego diffusion. The ego diffusion seen in merger states does, however, cause considerable discomfort within the relationship entity and is also limiting to the personal growth of the individuals within that relationship. It is these issues which bring psychologically merged couples into therapy. 
A high degree of interpersonal dependency has been implicated in many psychological disorders (Chodoff, 1972; Fenichel, 1945). It is also a common factor in clinical descriptions of psychological merger (Burch, 1982; Krestan \& Bebko, 1980). The term as used here describes a complex of "thoughts, beliefs, feelings and behaviors which revolve around the need to associate closely with, interact with and rely upon valued other people" (Corcoran \& Fischer, 1987, P. 203).

The Ego Identity Scale (EIS) (see Appendix D) (Jan, Kendis, Fine \& Porac, 1977) is a forced-choice twelve item questionnaire, one choice for each item representing ego identity and one representing ego diffusion. A series of studies involving 249 undergraduate students was conducted to obtain normative data. An ego identity score is obtained by assigning a score of one to each statement circled by the subject that reflects ego identity, and then summing the scores, a high score indicating strong ego identity.

The Interpersonal Dependency Inventory (IDI) (Hirschfield, Klerman, Gough, Barrett, Korchin, \& Chodoff, 1977) is a 48-item instrument (see Appendix E). The instrument contains three subscales, emotional reliance on others, lack of self-confidence and assertion of autonomy. The IDI was formed on three population samples, a group of 88 university males and 132 university females, a group of 76 male and 104 female psychiatric patients and a third group consisting of 19 male and 47 female psychiatric patients combined with 64 male and 57 female non-psychiatric community residents. Scores are obtained by rating each item from 1 to 4 ; from 1 , "not characteristic of me," to 4, "very characteristic of me." A sum of scores for each scale is obtained as 
well as a total score obtained by summing scale scores, a high score indicating strong interpersonal dependency.

It is important to note that the use of sex role scales and personality measuring instruments to generalize and predict behavior is a controversial area in research (Spence and Helmreich, 1980).

\section{PROCEDURE}

Each couple was mailed two identical questionnaire packets. Each indivicual received a cover letter, an informed consent form, an instruction sheet, a prepaid return envelope addressed to the author, the Extended Personal Attributes Questionnaire (EPAQ), the Interpersonal Dependency Inventory (IDI), the Ego Identity Scale (EIS) and a demographic sheet. (See Appendix B). Subjects were instructed to complete the questionnaire in one sitting and not to discuss the questionnaires until after they had been mailed back to the author.

The EPAQ items were scored obtaining F+ and M+ scores for each individual. Each subject was further classified into one of four sex role self-concept categories: masculine $\mathrm{M}+$ (high $\mathrm{Mt}$, low $\mathrm{F}+$ ), feminine $\mathrm{F}+$ (high $\mathrm{F}+$, low $\mathrm{M}+$ ), androgynous $\mathrm{A}$ (high $\mathrm{M}+$, high $\mathrm{F}+$ ) or undifferentiated U (low M+, low F+). Cut-off points for category classifications were determined by mean scores from previous research using the PAQ and EPAQ instruments (Spence \& Helmreich, 1978; Spence et al, 1979). In addition, subjects were scored for the three negative sex role categories measured by EPAQ. These categories are: negative masculinity (unmitigated agency) (M-), negative feminine verbal aggressive (Fva-) and negative feminine communion (unmitigated communion) (FC-). The tendency for the individual to be 
psychologically merged with a significant other was measured by the Ego Identity Scale (EIS) and the Interpersonal Dependency Inventory (IDI) . For these dependent variables, a high dependency score and a low ego identity score indicate a tendency for psychological merger.

Data were collected on 76 people but these were not independent measures as they were collected through coupled pairs. In order not to violate the assumptions of independent sample measurements, the investigator randomly assigned the members of each couple to one of two subsets: subset one, $\mathrm{n}=38$ and subset two, $\mathrm{n}=38$. The data for members of each couple were therefore separated. Analyses were conducted separately on the two subsets. 
CHAPTER III

RESUITS

COMPARISON OF SUBJECTS ON DEMOGRAPHIC AND BACKGROUND VARTABLES

Table I summarizes the independent and dependent variables and the range of possible scores a participant could have on each variable. (See Table I). The original versions of the scales for dependency and ego identity were constructed such that possible scores would range from 14 to 120 and 0 to 12 , respectively. These scales were linearly transformed to range 0 to 100 so that the meaning of particular scores could be more readily grasped and compared across outcomes.

In order to explore the differences in the four sex role self-concept categories -- Masculine (M), Feminine (F), Androgynous (A), and Undifferentiated (U) -- the following demographic and background variables were listed: age, income, education, length of current relationship, number of previous relationships, percent of subjects with children in their household and percent of subjects who own their own homes. As noted, data were analyzed separately for two subsets of participants ( $n=38$ in each group) in order not to violate the assumptions of independent measurements for these couples' data. Means and standard deviations on demographic variables for individuals in each sex role category and a pooled category (all women, $n=38$ ) are presented in Table II. As can be seen from the data for both subsets, 
TABLE I

CONSTRUCTS OF INTEREST CATEGORIZED BY

DEPENDENT AND INDEPENDENT VARIABLES

IDI

EIS

INDEPENDENT VARIABLE

EPAO

M+

F+

M-

SEX ROLE

SELF- CONCEPT GROUPS

Fva-

FC-

Extended Personal Attributes Questionnalre $(0-32)$ for each Category

Positively Valued

Masculine Traits (Agency)

Positively Valued

Feminine Traits (Communion)

Negat 1vely Valued

Masculine Traits

(Unmitigated Agency)

Negatively Valued

Feminine Verbal Aggressive

Traits.

Negatively Valued

Feminine Traits

(Unmitigated Communion)

Classification of subjects by Their M+ and $E+$ Scores using a Median Split Method

Range:

$-100$
Higher Score

Means More

Dependency

Higher Score Lower Score -

Means Stronger Greater Merger

Ego Function
Higher Score Greater Merger

Tendency

Tendency
Categories are: Higher Score - $\mathrm{M}+, \mathrm{F}+, \mathrm{M}-, \quad$ Means More of Fva-, FC- Category Trait

The Groups Are:

Masculine (M+

Feminine $(E+)$

Androgynous (A)

Undifferentiated (U)

Masculine (M)

Above the Median on M+ Below the Median on $\mathrm{Ft}$

Feminine (F)

Above the Median on $F+$ Below the Median on M+

Androgynous (A)

Above the Median on M+ Above the Median on $F+$ 
the study population was well educated, with an average of one year of graduate school. The subjects had a mean age of 36 years; they tended to be economically stable, with mean incomes of $\$ 22,000$ per year and with over $40 \%$ owning their own homes. Relationships seemed relatively stable with a mean duration of over six years for the two subsets and less than 2 previous relationships. (See Table II).

In the sex role self-concept categories, the masculine group in both sets of data had the highest income, largest percentage of home ownership and longest durations of current relationship (with the exception of one of the undifferentiated groups, which is suspect with an $n$ of two). One-way analyses of variance of sex role categories by demographic variables revealed no significant differences consistent to both subsets of participants.

DIFFERENCES AMONG SEX ROLE SELF-CONCEPT CATEGORIES IN PSYCHOLOGICAL MERGER TENDENCIES

The purpose of the analyses in this section was to determine if particular sex role self-concept categories differed significantly in the tendency to psychological merger as measured by the dependent variables, Interpersonal Dependency Inventory (IDI) and the Ego Identity Scale (EIS) (see Table I). One-way analyses of variance in subset \#2 considered four categories of the predictor variable, sex role self-concept (M, F, A, U). Membership in these categories was significantly related to interpersonal dependency, $\underline{F}(3,34)=7.334$, $\mathrm{p}<.001$; and for ego identity, $\underline{\underline{F}}(3,34)=4.196, \mathrm{p}<.01$. However, the same analyses in subset \#I failed to yield significant results; interpersonal dependency, $\underline{F}(3,34)=1.820, p<0.162$ and ego identity, $\underline{F}(3,34)=0.663, p<0.580$. 
TABLE II

MEAN DEMOGRAPHIC SCORES AND BACKGROUND VARIABLES BY SAMPLE SUBSET AND SEX ROLE SELF-CONCEPT GROUP

VARIABLE

\begin{tabular}{|c|c|c|c|c|c|c|c|c|}
\hline subject ractor & & Age & Income & rducution & $\begin{array}{c}\text { Longth } \\
\text { Relat lonship }\end{array}$ & $\begin{array}{l}\text { Preolous } \\
\text { Relationehipe }\end{array}$ & $\begin{array}{l}\text { with } \\
\text { chlldren }\end{array}$ & town \\
\hline \multicolumn{9}{|l|}{ SUBSET \#1 } \\
\hline All Women & $M$ & 34.63 & 22,760 & 17.08 & 6.18 & 1.47 & 168 & $42 \frac{8}{8}$ \\
\hline$(N=38)$ & s.d. & 6.28 & 16,126 & 3.35 & 4.44 & 1.50 & . & \\
\hline Masculine & $M$ & 38.29 & 37,428 & 16.71 & 9.14 & 1.57 & 148 & 718 \\
\hline$(N=7)$ & s.d. & 5.82 & 29,472 & 4.19 & 7.52 & 0.98 & & \\
\hline Feminine & $M$ & 34.75 & 20,137 & 17.12 & 6.25 & 1.25 & 258 & $38 \frac{8}{8}$ \\
\hline$(N=8)$ & s.d. & 6.41 & 6,910 & 4.39 & 3.24 & 0.89 & & \\
\hline Androgynous & $M$ & 33.10 & 19,040 & 17.10 & 5.30 & 1.65 & 108 & 408 \\
\hline$(\mathrm{N}=20)$ & s.d. & 5.79 & 9,364 & 2.97 & 3.18 & 1.87 & & \\
\hline Undifferentiated & $M$ & 36.00 & 20,333 & 17.67 & 5.00 & 0.67 & $33 \frac{\circ}{6}$ & 08 \\
\hline$(\mathrm{N}=3)$ & s.d. & 9.64 & 16,653 & 1.53 & 4.58 & 1.16 & & \\
\hline \multicolumn{9}{|l|}{ SUBSET \#2 } \\
\hline All Women & $M$ & 37.21 & 22,462 & 17.21 & 6.16 & 1.74 & $16 \%$ & 47 응 \\
\hline$(\mathrm{N}=38)$ & s.d. & 8.56 & 14,272 & 2.37 & 4.48 & 1.57 & & \\
\hline Masculine & $\mathrm{M}$ & 35.62 & 33,750 & 17.12 & 9.62 & 1.00 & $0 \%$ & $50 \%$ \\
\hline$(N=8)$ & s.d. & 8.26 & 23,119 & 3.52 & 6.74 & 1.19 & & \\
\hline Feminine & $M$ & 37.83 & 18,192 & 17.50 & 4.17 & 1.67 & $17 \%$ & $33 \div$ \\
\hline$(N=6)$ & s.d. & 12.69 & 6,137 & 2.17 & 2.23 & 1.63 & & \\
\hline Androgynous & $M$ & 37.54 & 20,336 & 17.18 & 4.86 & 2.09 & $18 \%$ & $45 \frac{8}{8}$ \\
\hline$(N=22)$ & s.d. & 8.17 & 10,268 & 2.13 & 2.73 & 1.66 & & \\
\hline Jndifferentiated & $M$ & 38.00 & 13,500 & 17.00 & 12.50 & 1.00 & 508 & $100 \%$ \\
\hline$(\mathrm{N}=2)$ & s.d. & 1.41 & 2,121 & 1.41 & 2.12 & 1.41 & & \\
\hline
\end{tabular}

*Refer to the Methods Section for an Explanation of Subset Fomation 
FEMININITY/MASCULINITY CATEGORIES IN PSYCHOLOGICAL MERGER TENDENCIES

An examination of the femininity/masculinity category scores was conducted to test the relationship of relative levels within each category (tertiles) to the tendency to psychological merger as measured by the constructs of dependency and ego identity. Table III shows descriptive measures of the femininity/masculinity categories.

TABLE III

MEAN EEMININITY/MASCULINITY (EPAQ) SCORES BY SAMPLE SUBSET

FEMININITY/MASCUIINITY CATEGORIES*

\begin{tabular}{|c|c|c|c|c|c|c|}
\hline SOURCE & & MH & $F+$ & $\mathbf{M}-$ & Eva- & Fc- \\
\hline SUBSET \#1 & $\mathbf{M}$ & 22.47 & 24.97 & 10.21 & 11.37 & 9.42 \\
\hline \multirow[t]{2}{*}{$(N=38)$} & s.d. & 3.91 & 4.40 & 4.46 & 5.79 & 6.77 \\
\hline & Median & 23.00 & 26.00 & 9.00 & 12.00 & 8.00 \\
\hline SUBSET \#2 & $M$ & 23.29 & 25.16 & 9.63 & 10.68 & 8.05 \\
\hline \multirow[t]{2}{*}{$(\mathrm{N}=38)$} & s.d. & 3.88 & 4.30 & 3.86 & 5.91 & 5.41 \\
\hline & Median & 23.50 & 24.50 & 10.00 & 10.00 & 8.00 \\
\hline
\end{tabular}

* NOTE - The Possible Range of Scores is 0 - 32 for each Femininity/Mascuininity Category

Each of the femininity/masculinity categories (M+, F+, M-, Fva-, and FC-) were divided into tertiles so that comparisons could be made between the participants at the opposite extremes of these scales. One-way analyses of variance were conducted to determine whether membership in the upper or lower tertile could significantly predict to level of interpersonal dependency or ego strength. For example, dependency scores of respondents in the high tertile for positive aspects of femininity $(\mathrm{F}+)$ were compared to the same scores for women in the low F+ tertile. Table IV presents the results of these ANOVA analyses. (See Table IV). 
The high/low tertile scores in the category of feminine verbal aggression (Fva-) were significantly related to both of the dependent variables. These findings held up in both subsets of participants. For dependency: subset $\# 1, \underline{F}(1,24)=6.089, p<.05$; subset \#2, $\underline{F}$ (1, $24)=20.378, p<.001$. For ego identity: subset \#I, $\underline{F}(1,24)=$ $5.515, \mathrm{p}<.05$; subset $\# 2, \underline{\mathrm{F}}(1,24)=20.102, \mathrm{p}<.001$.

The high/low tertile scores in the category of Feminine Negative Communion (FC -) were significantly related in both subsets of data to dependency. But only for subset \#I was negative communion related to ego identity. For dependency: subset $\# 1, \underline{F}(1,24)=22.696, p<.001$; subset \#2, $\underline{F}(1,24)=5.001, p<.05$. For ego identity: subset \#1, $\underline{F}$ $(1,24)=15.868, \mathrm{p}<.001$.

These results show that the traits of negative feminine verbal aggressive (Fva-) and negative feminine communion (FC-) are associated with higher levels of dependency in both subsets of data. The negative feminine verbal aggressive (Fva-) trait in both subsets of data and the negative feminine communion ( $\mathrm{FC}-$ ) trait in subset \#1 are associated with lower levels of ego identity.

The positive masculine (M+) trait category was associated with lower levels of dependency in subset \#2. Higher levels of ego identity were associated with the positive masculine (M+) trait category in both subsets of data. For dependency: subset \#2, F (1, $24)=12.702, p<.01$. For ego identity: subset $\# 1, \underline{F}(1,24)=$ $3.102, p<.05$; subset $\# 2, \underline{F}(1,24)=14.204, p<.001$.

The other sex role traits -- positive femininity $(F+)$ and negative masculinity (M-) -- were not significantly related either to dependency or ego identity. 
TABLE IV

SUMMARY OF ANALYSIS OF VARIANCE ON THE IDI AND EIS SCORES COMPARING THE UPPER AND LOWER TERTILES OF THE POSITIVE AND NEGATIVE EEMININE/MASCULINE (EPAQ) SCORES

(SUBSET \#1, $\mathrm{N}=26 ;$ SUBSET \#2, $\mathrm{N}=26$ )

\begin{tabular}{|c|c|c|c|c|}
\hline \multirow[b]{2}{*}{ SOURCE } & \multirow[b]{2}{*}{$\begin{array}{l}\text { DEPENDENT } \\
\text { VARIABIE }\end{array}$} & \multicolumn{2}{|c|}{ SCORE ON DEPENDENT VARIABLE } & \multirow[b]{2}{*}{ F } \\
\hline & & $\begin{array}{c}\text { UPPER } \\
\text { TERTILE, } \mathrm{N}=13\end{array}$ & $\begin{aligned} \text { LOWER } & \\
\text { TERTILE, } N & =13\end{aligned}$ & \\
\hline \multirow[t]{2}{*}{$\begin{array}{l}M+\text { SCORES } \\
\text { SUBSET \#1 }\end{array}$} & DEPENDENCY & $\begin{array}{lr}M & 32.243 \\
\text { s.d. } & 4.863 \\
\end{array}$ & $\begin{array}{lr}M & 35.227 \\
\text { S.d. } & 5.511 \\
\end{array}$ & 2.141 \\
\hline & EGO IDENTITY & $\begin{array}{ll}\text { M } & 74.329 \\
\text { s.d. } & 16.819\end{array}$ & $\begin{array}{ll}M & 63.436 \\
\text { s.d. } & 14.642\end{array}$ & $\begin{array}{l}\star(1) \\
3.102\end{array}$ \\
\hline \multirow[t]{2}{*}{$\begin{array}{l}\text { M+ SCORES } \\
\text { SUESET \#2 }\end{array}$} & DEPENDENCY & $\begin{array}{lr}\text { M } & 28.538 \\
\text { s.d. } & 3.778\end{array}$ & $\begin{array}{lr}\text { M } & 34.431 \\
\text { S.d. } & 4.613\end{array}$ & $\star \star 12.702$ \\
\hline & EGO IDENTITY & $\begin{array}{ll}\text { M } & 76.253 \\
\text { s.d. } & 14.369\end{array}$ & $\begin{array}{l}\mathrm{M} \\
\text { s.d. } \\
14.103 \\
\end{array}$ & $\star * \star 14.204$ \\
\hline \multirow[t]{2}{*}{$\begin{array}{l}F+\text { SCORES } \\
\text { SUBSET \#1 }\end{array}$} & DEPENDENCY & $\begin{array}{lr}M & 34.899 \\
\text { S.d. } & 4.117 \\
\end{array}$ & $\begin{array}{lr}M & 34.498 \\
\text { s.d. } & 6.432 \\
\end{array}$ & .036 \\
\hline & EGO IDENTITY & $\begin{array}{ll}\text { M } & 63.433 \\
\text { s.d. } & 22.441\end{array}$ & $\begin{array}{ll}M & 61.517 \\
\text { S.d. } & 16.843\end{array}$ & .061 \\
\hline \multirow[t]{2}{*}{$\begin{array}{l}F+\text { SCORES } \\
\text { SUBSET \#2 }\end{array}$} & DEPENDENCY & $\begin{array}{lr}\text { M } & 31.221 \\
\text { s.d. } & 4.157\end{array}$ & $\begin{array}{lr}\text { M } & 30.127 \\
\text { s.d. } & 5.842\end{array}$ & .302 \\
\hline & EGO IDENTITY & $\begin{array}{ll}\text { M } & 69.206 \\
\text { S.d. } & 14.969\end{array}$ & $\begin{array}{ll}M & 69.206 \\
\text { S.d. } 20.225\end{array}$ & .000 \\
\hline \multirow[t]{2}{*}{$\begin{array}{l}\text { M- SCORES } \\
\text { SUBSET \#1 }\end{array}$} & DEPENDENCY & $\begin{array}{lr}\text { M } & 35.839 \\
\text { S.d. } & 5.989 \\
\end{array}$ & $\begin{array}{lr}M & 33.729 \\
\text { S.d. } & 4.372 \\
\end{array}$ & 1.052 \\
\hline & EGO IDENTITY & $\begin{array}{ll}\text { M } & 58.310 \\
\text { s.d. } & 17.343\end{array}$ & $\begin{array}{l}\text { M } 70.488 \\
\text { s.d. } 19.717\end{array}$ & 2.795 \\
\hline \multirow[t]{2}{*}{$\begin{array}{l}\text { M- SCORES } \\
\text { SUBSET \#2 }\end{array}$} & DEPENDENCY & $\begin{array}{lr}M & 30.271 \\
\text { s.d. } & 5.903 \\
\end{array}$ & $\begin{array}{lr}M & 31.508 \\
\text { s.d. } & 3.934 \\
\end{array}$ & .396 \\
\hline & EGO IDENTITY & $\begin{array}{l}\text { M. } 71.763 \\
\text { s.d. } 21.383 \\
\end{array}$ & $\begin{array}{ll}M & 67.281 \\
\text { s.d. } & 12.936\end{array}$ & .419 \\
\hline \multirow[t]{2}{*}{$\begin{array}{l}\text { Fva- SCORES } \\
\text { SUBSET \#I }\end{array}$} & DEPENDENCY & $\begin{array}{lr}\text { M } & 36.973 \\
\text { s.d. } & 5.615\end{array}$ & $\begin{array}{lr}M & 31.985 \\
\text { s.d. } & 4.647\end{array}$ & $\star 6.089$ \\
\hline & EGO IDENTITY & $\begin{array}{ll}\mathrm{M} & 57.669 \\
\text { S.d. } & 15.002 \\
\end{array}$ & $\begin{array}{lr}M & 73.687 \\
\text { S.d. } & 19.492 \\
\end{array}$ & $\star 5.515$ \\
\hline \multirow[t]{2}{*}{$\begin{array}{l}\text { Fva- SCORES } \\
\text { SUBSET } \# 2\end{array}$} & DEPENDENCY & $\begin{array}{lr}M & 36.804 \\
\text { S.d. } & 4.056 \\
\end{array}$ & $\begin{array}{lr}M & 27.638 \\
\text { S.d. } & 3.756 \\
\end{array}$ & $\star \star \star 20.378$ \\
\hline & EGO IDENTITY & $\begin{array}{ll}\text { M } & 55.103 \\
\text { S.d. } & 12.512 \\
\end{array}$ & $\begin{array}{ll}\text { M } & 79.452 \\
\text { S.d. } & 15.061\end{array}$ & $\star \star \star 20.102$ \\
\hline \multirow[t]{2}{*}{$\begin{array}{l}\text { FC- SCORES } \\
\text { SUBSET \#1 }\end{array}$} & DEPENDENCY & $\begin{array}{lr}M & 38.086 \\
\text { S.d. } \quad 4.699 \\
\end{array}$ & $\begin{array}{lr}M & 30.256 \\
\text { S.d. } \quad 3.611 \\
\end{array}$ & $\star * \star 22.696$ \\
\hline & EGO IDENTITY & 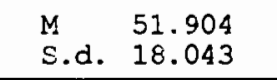 & $\begin{array}{l}\mathrm{M} \\
\text { s.d. } 16.253 \\
12.653\end{array}$ & $\star \star \star 15.868$ \\
\hline \multirow[t]{2}{*}{$\begin{array}{l}\text { FC- SCORES } \\
\text { SUBSET \#2 }\end{array}$} & DEPENDENCY & $\begin{array}{lr}M & 33.933 \\
\text { S.d. } & 4.005 \\
\end{array}$ & $\begin{array}{lr}\text { M } & 29.596 \\
\text { s.d. } & 5.730 \\
\end{array}$ & $\star 5.001$ \\
\hline & EGO IDENTITY & $\begin{array}{ll}\text { M } & 64.716 \\
\text { S.d. } & 19.584\end{array}$ & $\begin{array}{ll}\text { M } & 71.763 \\
\text { s.d. } & 17.185\end{array}$ & .952 \\
\hline
\end{tabular}


TABLE IV

SUMMARY OF ANALYSIS OF VARIANCE ON THE IDI AND EIS SCORES COMPARING THE UPPER AND LOWER TERTILES OF THE POSITIVE AND NEGATIVE FEMININE/MASCULINE (EPAQ) SCORES (continued)

a. df $-1,24$

${ }^{\star} p<.05 .{ }^{\star \star} p<.01 .{ }^{*} \star \star p<.001$.

NOTE: $M+$ - Positively valued masculine traits (Agency)

$\mathrm{Ft}=$ Positively valued feminine traits (Communion)

$M-=$ Negatively valued masculine traits (Unmitigated Agency)

Fva- = Negatively valued feminine verbal aggressive traits

$\mathrm{FC}^{-}=$Negative valued feminine communion traits (Unmitigated Communion)

(1) Significant with a one-tail test - specific directions were hypothesized, therefore, one-tailed test is sufficient.

\section{DISTRIBUTION OF INDIVIDUALS BY SEX ROIE SELF-CONCEPT CATEGORY}

Table $\mathrm{V}$ shows the distribution of individuals across sex role self-concept categories (M, F, A, U) by sample subset. There is a predominance of androgynous individuals in both subsets $153 \%$ and 58\%). (See Table V) DISTRIBUTION OF PARTNERS WITHTN COUPLES BY SEX ROLE SEIF-CONCEPT
CATEGORTES

The distribution of partners by sex role self-concept is cross-tabulated in Table VI. Observation of this table suggests a preference for masculine (M) or androgynous (A) women to pair with masculine (M) or androgynous (A) partners. In order to examine this possibility analytically, a second cross-tabulation table was prepared redistributing partners by high masculine categories $(M, A)$ and low masculine categories (F, U). Table VII shows that for this sample, in $57.9 \%$ of the couples both partners were high masculine category types 
TABLE V

\section{DISTRIBUTION OF INDIVIDUALS BY SEX ROLE \\ SEIF-CONCEPT CATEGORIES}

\begin{tabular}{|c|c|c|c|c|}
\hline SUBSET & M & $F$ & A & $\mathrm{U}$ \\
\hline $\begin{array}{l}\text { SUBSET \#1 } \\
\mathrm{N}=38\end{array}$ & $\begin{array}{c}7 \\
(188)\end{array}$ & $\begin{array}{c}8 \\
(218)\end{array}$ & $\begin{array}{c}20 \\
(538)\end{array}$ & $\begin{array}{c}3 \\
(8 \%)\end{array}$ \\
\hline $\begin{array}{l}\text { SUBSET } \# 2 \\
\mathrm{~N}=38\end{array}$ & $\begin{array}{c}8 \\
(218)\end{array}$ & $\begin{array}{c}6 \\
(16 \%)\end{array}$ & $\begin{array}{c}22 \\
(588)\end{array}$ & $\begin{array}{c}2 \\
(58)\end{array}$ \\
\hline
\end{tabular}

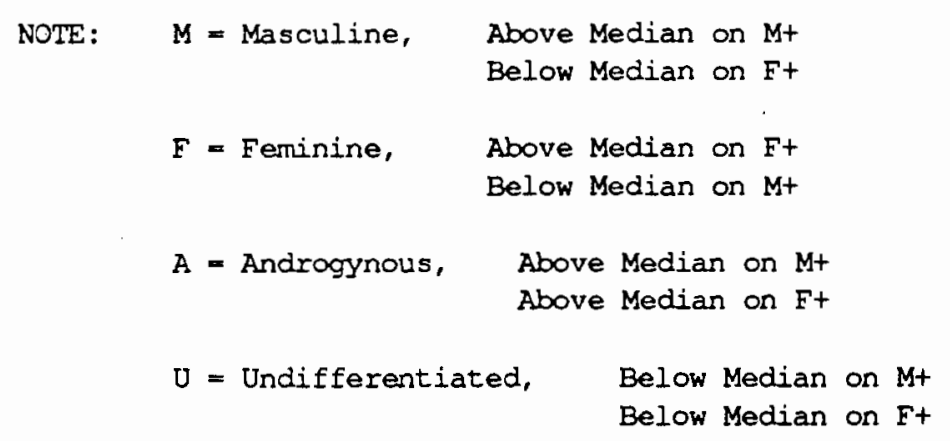

$(\mathrm{M}, \mathrm{A})$, in $7.9 \%$ of the couples both partners were low masculine category types $(F, U)$ and in $34.2 \%$ of the couples partners were mixed, one high masculine (M, A) and one low masculine $(F, U)$. Chi-square analyses of both tables (VI and VII) revealed no significant relationships between sex role combinations within couples. (See Tables VI and VII.) 
TABLE VI

DISTRIBUTION OF PARTNERS BY SEX ROLE SELF-CONCEPT CATEGORIES

\begin{tabular}{|c|c|c|c|c|c|}
\hline \multirow[b]{2}{*}{ PARTNER 1} & \multicolumn{5}{|c|}{ PARTNER 2} \\
\hline & M & F & $A$ & $\mathrm{U}$ & $x 2(9)$ \\
\hline \multicolumn{5}{|c|}{ TOTAL SAMPLE $(N=38)$} & \multirow{5}{*}{6.24} \\
\hline $\begin{array}{l}\text { MASCULINE } \\
\text { (M) }\end{array}$ & $\begin{array}{c}2 \\
(5.38)\end{array}$ & $\begin{array}{c}1 \\
(2.68)\end{array}$ & $\begin{array}{c}5 \\
(13.28)\end{array}$ & 0 & \\
\hline $\begin{array}{l}\text { FEMININE } \\
\text { (F) }\end{array}$ & 0 & $\begin{array}{c}2 \\
(5.38)\end{array}$ & $\begin{array}{c}4 \\
(10.58)\end{array}$ & 0 & \\
\hline $\begin{array}{l}\text { ANDROGYNOUS } \\
\text { (A) }\end{array}$ & $\begin{array}{c}5 \\
(13.28)\end{array}$ & $\begin{array}{c}4 \\
(10.58)\end{array}$ & $\begin{array}{c}10 \\
(26.38)\end{array}$ & $\begin{array}{c}3 \\
(7.98)\end{array}$ & \\
\hline $\begin{array}{l}\text { UNDIFFERENTIATED } \\
\text { (U) }\end{array}$ & 0 & $\begin{array}{c}1 \\
(2.6 q)\end{array}$ & $\begin{array}{c}1 \\
(2.68)\end{array}$ & 0 & \\
\hline
\end{tabular}

TABLE VII

DISTRIBUTION OF PARTNERS BY COMBINED

SEX ROLE SELF-CONCEPT CATEGORIES

PARTNER 2

\begin{tabular}{|lcc|c|} 
PARTNER 1 & (M OR A) & $(E$ OR U) & $X$ 2(1) \\
\hline & Total Sample $(\mathrm{N}=38)$ & \\
MASCULINE OR ANDROGYNOUS & 22 & 8 & \\
(M OI A) & $(57.98)$ & $(21.08)$ & .36 \\
FEMININE OR UNDIFFERENTIATED & 5 & 3 & \\
(F OI U) & $(13.2 \%)$ & $(7.9 \%)$ & \\
\hline
\end{tabular}


DISTRIBUTION OF PARTNERS BY NEGATIVE SEX ROLE TRAIT TERTILES

An investigation was conducted to determine whether partners tended to pair according to negative sex role traits. Table VIII shows the distribution of partners across negative sex role trait categories according to tertile position. In this table, high means the upper one-third of negative trait scores, low means the lower one-thind of negative trait scores and middle indicates the central one-third of scores.

The higher scores indicate that the individual has more of the negative trait. Chi-square analyses were conducted on each of the nine blocks of cells in Table VIII. The analyses showed no significant relationship between the negative sex role self-concept tertile combinations within couples. (See Table VIII.) 
TABIE VIII

DISTRIBUTION OE' PARTNERS BY NEGATIVE

SEX ROLE TRAIT TERTILES

(TOTAL SAMPLE $N=38$ )

PARTNER 2

\begin{tabular}{|c|c|c|c|c|c|c|c|c|c|}
\hline \multirow[b]{2}{*}{ PARTNER 1} & \multicolumn{3}{|c|}{$\begin{array}{l}\text { NEGATIVE FEMININE } \\
\text { COMMUNION (EC-) }\end{array}$} & \multicolumn{3}{|c|}{$\begin{array}{c}\text { NEGATIVE FEMININE } \\
\text { VERBAL AGGRESSIVE (FVa-) }\end{array}$} & \multicolumn{3}{|c|}{$\begin{array}{l}\text { NEGATIVE MASCULINE } \\
(\mathrm{M}-)\end{array}$} \\
\hline & $\mathrm{HIGH}$ & MIDDIE & LOW & HIGH & MIDDIE & IOS & $\mathrm{HIGH}$ & MIDDIE & LOW \\
\hline \multicolumn{10}{|l|}{$(F c-)$} \\
\hline HIGH & 6 & 3 & 4 & 4 & 4 & 5 & 4 & 3 & 6 \\
\hline MIDDLE & 5 & 3 & 4 & 3 & 5 & 4 & 6 & 4 & 2 \\
\hline IOW & 2 & 6 & 5 & 6 & 3 & 4 & 3 & 5 & 5 \\
\hline \multicolumn{10}{|l|}{ (Eva-) } \\
\hline HIGH & 3 & 5 & 5 & 6 & 3 & 4 & 7 & 3 & 3 \\
\hline MIDDLE & 6 & 2 & 4 & 3 & 4 & 5 & 3 & 3 & 6 \\
\hline IOW & 4 & 5 & 4 & 4 & 5 & 4 & 3 & 6 & 4 \\
\hline \multicolumn{10}{|l|}{$(M-1$} \\
\hline HIGH & 3 & 2 & 8 & 4 & 3 & 6 & 4 & 3 & 6 \\
\hline MIDDIE & 6 & 4 & 2 & 7 & 1 & 4 & 3 & 5 & 4 \\
\hline LOW & 4 & 6 & 3 & 2 & 8 & 3 & 6 & 4 & 3 \\
\hline
\end{tabular}


CHAPTER IV

\section{DISCUSSION}

This study was undertaken to explore the femininity/masculinity sex role traits as they relate to psychological merger in lesbian relationships. Much of the literature on lesbian relationships links the feminine relational capacity with the problem of psychological merger (Burch, 1982, 1985; Decker, 1984; Elise, 1986; Krestan and Bepko, 1980). Separation-individuation theory proposes that this female relational capacity is related to the female's experiences in gender development, in which her gender sameness to mother does not allow psychological differentiation from the mother to be as complete for a girl as for a boy. Ego boundaries are less firmly formed, allowing females a greater relational capacity than males. A result of this is that "women may have more difficulty experiencing themselves as separate, and a greater tendency toward psychological merger in intimate relationships" (Burch, 1982, p. 202). Intimate relationships involving two women are theorized to be more likely to experience problems with psychological merger than are heterosexual or gay male couples where the male tendency toward autonomy balances the relationship (Decker, 1984; Krestan and Bepko, 1980).

Heterosexual and gay male relationships face problems of a different nature. Studies comparing relationship quality and satisfaction in heterosexual, lesbian, and gay male couples (Blumstein and Schwartz, 1983; Decker, 1984; Kurdek: and Schmitt, 1986b) report 
problems in heterosexual relationships where males seek distance while females desire more closeness. Gay male couples report difficulty with relationship nurturing skills, gay men tending to be overly competitive with their partners and inclined to 'distancing' when their relationships are in difficulty.

The psychodynamic theories seem to be implying that feminine relational capacity is on a continurm - if the feminine trait constitutes one-half of a relationship, as in heterosexual couples, it is considered healthy; if the trait is found in both members of a couple, as in lesbian relationships, it can lead to pathology i.e. psychological merger. A little of the trait is healthy but too much of the trait is potentially harmful. This 'continuum' concept has persisted for years concerning the developmental process of intimacy and autonomy. Early theorists (Fairbairn, 1952; Mahler, 1974) saw ego development as movement from merger with the mother to the mature ideal of an autonomous self. A recent theoretical proposal by Stern (1983) retains the 'continuum' concept of development while reversing the direction of movement. Stern theorizes that the infant moves from autonomy to the capacity for intimacy. Empirical studies (Peplau, 1978; Raney, 1976; Raush, 1977) have challenged the 'continuum' concept of autonomy and intimacy showing that these traits are independent dimensions following separate developmental pathways.

Developmental theories which place autonomy and intimacy on opposite ends of a continuum, with the exception of Stern's theory, have devalued the feminine identified developmental pathway (intimacy) proclaiming autonomy the developmental goal of adulthood. Similarly, the concept that excessive intimacy in relationship leads to pathology 
(merger) reflects a devaluing of the feminine identified trait of intimacy.

My study was undertaken to empirically address the idea that the female relational trait, compounded in a lesbian relationship, is related to the tendency for an individual to become psychologically merged in relationship. I theorized that it was not the positive female relational trait but the negative feminine traits -urmittigated communion and passive verbal aggression -- that relate to the tendancy to psychological merger.

The femininity/masculinity (EPAQ) questionnaire developed by Spence, Helmreich, and Holahan (1979) provided a means of exploring how both positive and negative male and female sex role traits relate to the indicators of psychological merger, dependency and ego identity.

\section{REIATIONSHIP BETWEEN FEMININITY/MASCULINITY SEX ROIE TRAIT SCORES AND THE INDICATORS OF PSYCHOLOGICAL MERGER: DEPENDENCY AND EGO IDENIITIY}

When the attribute, relational capacity, is discussed by theorists, there is no distinction made between an individual's sense of impact on others and the sense of how others impact on the individual. The femininity/masculinity (EPAQ) scale makes this distinction. The positive feminine $(F+)$ trait category explores an individual's sense of relational impact on others. A high score indicates a strong interest in relating to and caring for others. The negative feminine communion (FC-) trait category measures a different construct, the individual's sense of how others impact on her. A high FC- score indicates a sense of powerlessness in relation to others. 
The negative feminine verbal aggressive (Fva-) trait category measures passive-aggressive verbal behavior. Her perceived sense of powerlessness does not allow her to respond directly to others.

My findings indicate that the positive masculine (M+) trait scores -- which indicate an individual's sense of agency, and the positive female trait scores $(\mathrm{F}+)$ - the measure of an individual's sense of relational impact on others, have no direct association with the tendency to psychological merger. ANOVA results on the sex role self-concept categories -- masculine (M), feminine (F), androgynous (A), and undifferentiated (U) -- showed no significant relationships between these positive trait constructs and the indicators of psychological merger, which were dependency - a high score indicating strong dependency on others, and ego identity - a low score indicating identity diffusion. As predicted it is the negative feminine traits, negative feminine (umitigated) communion (FC-) and negative feminine verbal aggression (Fva-) that are significantly related to the indicators of psychological merger, high dependency and low ego identity. This finding is consistent with previous theoretical and empirical work (Bakan, 1966; Spence et al., 1978, 1979, 1980) suggesting that the conmunion trait unmitigated by a sense of agency is detrimental to the individual and to relationships.

The sense of personal powerlessness associated with the FC- and Fva - constructs relates to high dependency on significant others and a low sense of ego identity. The positive masculine (M+) trait category associated significantly to low dependency and high ego identity scores. The positive masculine trait $(\mathrm{M}+)$ is a measure of an individual's sense of agency or ability to affect one's environment, 
i.e. personal power. These results are consistent with the concept that a strong sense of personal power over one's environment is beneficial to psychological health (Pearlin, 1971).

REIATIONSHIP BEIWEEN POSITIVE AND NEGATIVE FEMININITY/MASCUITNITY SCORES

The ANOVA results show that the positive feminine relational trait $(\mathrm{F}+)$ does not relate to the indicators of psychological merger, while the negative feminine traits FC- and Fva- do.

The next question addressed was, how do the positive and negative traits relate to each other? Table IX shows the inter-correlations of positive and negative trait scores by sample subset. (As a reminder to the reader, data from these coupled individuals were divided randomly into two subgroups in order to preserve a relative independence of subjects' scores.)

The positive masculine (M+) category correlated negatively with the negative feminine communal ( $F C-$ ) and the negative feminine verbal aggressive (Fva-) traits in both subsets of data. The positive feminine $\left(\mathrm{F}^{+}\right)$trait category was unrelated to levels of the negative feminine traits ( $\mathrm{FC}^{-}, \mathrm{Fva}-$ ).

It is important to note the lack of correlation between the negative and positive feminine traits. This allows one to see that these are independent constructs rather than opposite ends of a single feminine relational continuum. The negative feminine traits FC- and Fva- are not related to high scores on the positive feminine F+ trait category. This finding challenges the "continuum' concept that too 
CORRELATIONS BETWEEN POSITIVE SEX ROLE TRAIT SCORES

AND NEGATIVE SEX ROLE TRAIT SCORES

BY SAMPLE SUBSET

\begin{tabular}{|c|c|c|c|}
\hline \multirow[b]{3}{*}{$\begin{array}{l}\text { NEGATIVE SEX ROLE } \\
\text { TRAIT }\end{array}$} & & \multicolumn{2}{|c|}{ POSITIVE SEX ROLE TRAIT } \\
\hline & & $\begin{array}{l}\text { POSITIVE MASCULINITY } \\
(\mathrm{M}+)\end{array}$ & $\begin{array}{c}\text { POSITIVE FEMININITY } \\
(\mathrm{F}+1)\end{array}$ \\
\hline & & & \\
\hline NEGATIVE & SUBSET 1 & $-.494 \star \star \star$ & -.028 \\
\hline FEMININE & $(N=38)$ & & \\
\hline $\begin{array}{l}\text { COMMUNION } \\
\left(\mathrm{F}^{\prime} \mathrm{C}-\right)^{-}\end{array}$ & $\begin{array}{l}\text { SUBSET } 2 \\
(\mathrm{~N}=38)\end{array}$ & $-.503 * \star \star$ & -.075 \\
\hline NEGATIVE & SUBSET 1 & $-.354 *$ & -.0236 \\
\hline FEMININE & $(N=38)$ & & \\
\hline VERBAI & SUBSET 2 & $-.382 \star$ & .079 \\
\hline $\begin{array}{l}\text { AGGRESSION } \\
\text { (Eva-) }\end{array}$ & $(N=38)$ & & \\
\hline NEGATIVE & SUBSET $I$ & .180 & $-.368 \star$ \\
\hline MASCULINE & $(\mathrm{N}=38)$ & & \\
\hline$(M-)$ & $\begin{array}{l}\text { SUBSET } 2 \\
(N=38)\end{array}$ & .074 & -.263 \\
\hline
\end{tabular}

$\begin{array}{ll}\star \star \star & P<.01 \\ \star \star \quad & P<.02 \\ \star \quad & P<.05\end{array}$

much of the feminine relational trait $(\mathrm{F}+)$, as experienced in lesbian relationships, can lead to the pathological state of psychological merger.

The significant negative correlation between the positive masculine (M+) category and the negative feminine (FC-, Fva-) categories is consistent with the concept that a sense of powerlessness -- low agency $(\mathrm{M}+$ ) score -- associates with higher levels of the negative feminine communion (FC-) and negative feminine verbal aggressive (Fva-) trait categories. 
DISTRIBUTION OF INDIVIDUAIS AND PARTNERS BY SEX ROLE SEIF-CONCEPT CATEGORIES

The ANOVA and correlational results indicate that the tendency to psychological merger is not related to high levels of the female relational capacity $(F+)$, nor is this capacity related to the negative feminine traits (FC-) and (Fva-). Merger does relate, however, to high levels of the negative feminine traits (FC-) and (Fva-) which in turn correlate negatively with the positive masculine trait (M+) - low levels of M+ correlate with high levels of FC- and Fva-.

Because M+, FC-, and Fva- are the constructs related to merger, I wanted to explore these traits as they appear among lesbians. One way to measure the levels of the $M+$ trait is to categorize individuals by sex role self-concept categories; Masculine, Feminine, Androgynous, and Undifferentiated (Table I). Both the Masculine and Androgynous categories indicate individuals with high positive masculine (M+) scores. The distribution of individuals across the four sex role self-concept categories, Table $V$, shows that $71 \%$ of the women in subset $\# 1$ and $79 \%$ of the women in subset \#2 were either masculine or androgynous. These findings are consistent with other studies of lesbians' sex role identity (Heilbrun and Thompson, 1977; Kurdek and Schmitt, 1986). Chi-square analysis of sex role identity by partner combination yielded no significant results. In other words, partner combinations did not follow any matching or balancing trend i.e., masculine with masculine or masculine with feminine. 
DISTRIBUTION OF PARINERS BY NEGATIVE SEX ROLE TRAIT TERTILES

Chi-square analyses of the negative feminine traits (FC- and Fva-) were conducted to determine if there was any matching or balancing of negative traits within couples. There appears to be no relationship between levels of negative trait scores and an individual's choice of partner. Further studies are needed to investigate the relationship between positive and negative sex role traits and partner choice. No studies exist to compare negative sex role traits between heterosexual, gay male and lesbian populations.

\section{IMPLICATIONS OF THIS STUDY}

This study has shown that the capacity for intimacy as measured by the positive feminine trait $(\mathrm{F}+)$ is not related to indicators of psychological merger, high dependency and low ego identity. These results have also shown that intimacy $(\mathrm{F}+)$ is not the same as the negative feminine traits (Fc-, Fva-) which are related to the predictors of psychological merger. This study also revealed a negative correlation between the positive masculine trait (M+) and the negative feminine traits (FC-, Fva-) indicating that high masculine (M+) scores would be associated with a low likelihood of merger (low scores on the M+ trait related to high scores on the FC- and Fvatraits).

What do these findings imply? Research and clinical references to psychological merger should not link psychological merger to global statements about the feminine relational capacity (intimacy). This study does not support the assumption that psychological merger is 
related to the positive feminine capacity for intimacy. Positive $(F+)$ and negative (FC-, Fva-) femininity are unrelated constructs which both affect relationship functioning. It is, however, the negative components - umitigated communion ( $\mathrm{FC}^{-}$) and verbal passive aggression (Fva-) - which relate to the indicators of merger, high dependency and low ego identity.

The link between high scores on the negative feminine traits (FC-, Fva-) and low scores on the positive masculine agentic trait (M+) indicates that merger tendency is related to a sense of powerlessness. The focus on the issue of psychological merger in lesbian relationships needs to be shifted from an emphasis on the purported harmful effect of too much of the feminine relational trait $(\mathrm{F}+)$, i.e. intimacy, to an emphasis on the effects of perceived powerlessness.

The clinical literature suggests that some lesbians have problems of merger. What the current data suggest is that some lesbians feel powerless. To some extent, feelings of powerlessness might even be viewed as a realistic assessment of one's life situation in a society inimical to same-sex relationships.

Another interesting aspect of the low scores on the masculine (M+) trait being linked to psychological merger is that studies have shown lesbians to consistently score high on the M+ trait (Heilbrun and Thompson, 1977; Kurdek and Schmitt, 1986) and therefore should theoretically be relatively insulated from the tendency to psychologically merge.

The present study suggests that the presence of positive, agentic traits serves as a buffer against the tendency to depend too much on another person. And as the studies just cited have shown, lesbians 
actually have more of these positive masculine $(M+)$ traits than do non-lesbian women.

Why, then, is psychological merger observed so often in clinical work with lesbian relationships? The current writer proposes four reasons.

First, lesbian relationships respond to pressures that originate in society. In studies about merger in lesbian couples (Burch, 1982; Decker, 1984; Krestan \& Bepko, 1980) the authors stress that society's homophobic hostility toward lesbian relationship combined with the lack of legal sanctions and family support structures is antagonistic to lesbian relationship. In her study of same-sex couples, Mendola (1980) argues convincingly that societal homophobia against lesbians is a persistent threat to the duration of lesbian relationships. The lack of legal recognition for lesbian couples and the history of legal rulings against lesbians for custody of their children underline the general societal attitudes. Removing laws that discriminate against homosexuality does little to amend society's hostility toward homosexuals (Gagnon \& Simon, 1968).

A second source of threat to sustained lesbian relationship comes from within the lesbian community. Krestan and Bepko (1980) have written about two forms of pressure exerted on lesbian couples by the lesbian community. 1) Some more radical members of the women's movement feel that it is politically suspect for two women to form a monogamous relationship which resembles the heterosexual culture, thus, they view all forms of monogamy as a 'sellout' to the patriarchal culture. 2) In addition to the political attack on lesbian monogamy, Krestan and Bepko (1980) write that "gay couples are constantly 
vulnerable to the claims exerted by the community of gay women at large, who rarely respect the boundaries a couple draws around itself" (p. 285) .

Thirdly, the validity of the use of sex role scales is a controversial area in research (Spence and Helmreich, 1980). The assigmment of sex role traits to individuals based on instrumental and expressive trait dimensions pertains only to the domains of instrumentality and expressiveness. It is important to realize that behavior in any situation is influenced by a complex combination of variables -- instrumentality and expressiveness being only two possible variables. Caution must be exercised in generalizing the findings in any particular situation.

The situational view of the validity of sex trait typing could help explain the apparent contradictions found in this study concerning the observation that lesbians score high on the masculine (M+) trait and yet merger relates to low M+ scores.

How can one reconcile that the lesbian is high in the masculine $(\mathrm{M}+)$ trait and yet seems to struggle with merger issues in her relationships?

A possible explanation is that the lesbian woman is highly instrumental in some situations and not in others. The lesbian woman must exercise instrumental behavior in order to challenge a society that would deny her sexuality. She also draws on her instrumental skills in order to make a living as an essentially single woman (a woman without the economic advantage of a male partner). Instrumentality in these situtions does not predict instrumentality in her relationship dynamics. Other factors, such as her intra-psychic 
need for closeness, her perception of her partner's desire for closeness or distance and external social pressures also influence her ability to function effectively in her environment separate from her partner.

Finally, the prevalence of lesbians seeking clinical help for relationship problems may reflect the gender socialization of women. Iillian Rubin (1983) writes that women are socialized to take care of their relationships and to attend to relational problems. In addition, the greater tendency of women than men to seek professional help for personal problems is well - documented (Veroff, Kulka \& Dourvan, 1981). This author suggests that the tendency for lesbian relationships to merge is primarily influenced by negative pressures on lesbian couples from the larger society as well as from within the lesbian subculture; and that these pressures can result in psychological merger is due to the gender socialization of women.

If social pressure was the only factor in merger then one would expect gay male couples to also have merger problems. However, gay male couples do not generally experience merger problems (Elise, 1986) and in fact, frequently report problems with relationship distancing (Bell \& Weinberg, 1978).

These findings suggest that merger is a gender issue (not a lesbian issue). The idea that the female developmental process can predispose a woman to be susceptible to merger is consistent with theoretical views on feminine development (Chodororow, 1978; Gilligan, 1982). 
It could be argued that the tendency for psychological merger to occur is formed in the developmental experience of most women. Furthermore, the prevalence of merger in lesbian couples could be partly attributed to the joining of this trait in a relationship involving two women.

It is this author's view that it is the developmental experience of women in general that explains the female's susceptibility to merger; and that the prevalence of merger in lesbian couples attests to the strength of the social pressures against sustained lesbian relationship.

The findings reported here promote a better understanding of these issues that is critical to both the understanding and valuation of women's development and the proper choice of therapeutic interventions for lesbians seeking professional help. 
REFERENCES

Alperson, B.L., Freidman, W.J. (1983). Some aspects of interpersonal phenomenology of heterosexual dyads with respect to sex-role stereotypes. Sex Roles, 9 (4), 453-474.

American Psychiatric Association (1987). Diagnostic and statistical manual of mental disorders (3rd ed. -- Revised). Washington, DC: Author.

Bakan, D., (1966). The quality of human existence. Chicago: Rand MaNally.

Bell, A., and Weinberg, M. (1978). Homosexualities: A Study of Diversity Among Men and Women. New York: Simon and Schuster.

Bem, S.L. (1974). The measurement of psychological androgyny. Journal of consulting and Clinical Psychology, 42, 155-162.

Blumstein, P., and Schwartz, P. (1983). American Couples. New York: William Morrow and company.

Burch, B. (1982). Psychological merger in lesbian couples: A joint ego psychological and systems approach. Family Therapy, 9 (3), 201-208.

Burch, B. (1985). Another perspective on merger in lesbian relationships. In L.B. Rosewater \& L. Walker (Eds.), Handbook of feminist therapy: Women's issues in psychotherapy (pp. 100-109). New York: Springer.

Chodoff, P. (1972). The depressive personality: A critical review. International Joumal of Psychiatry, 27, 196-217.

Chodorow, N. (1978). The reproduction of mothering:

Psychoanalysis and the sociology of gender. Berkeley: University of California Press.

Chodorow, N. (1980). Gender, relation, and difference in psychoanalytic perspective. In $\mathrm{H}$. Eisenstein and A. Jardine (Eds.), The future of difference (pp. 3-19). Boston: G.K. Hall.

Corcoran, K., \& Fischer, J. (1987). Measures for Clinical practice: A sourcebook. New York: Macmillan.

Decker, B. (1984). Counseling gay and lesbian couples. Journal of Social Work and Human Sexuality, 2 (2-3), 39-52. 
Dinnerstein, D. (1977). The Mermaid and the minotaur: Sexual arrangements and human malaise. New York: Harper \& Row.

Elise, D. (1986). Lesbian couples: The implications of sex differences in separation-individuation. Psychotherapy, 23 (2), 305-310.

Erikson, E.H. (1950). Childhood and society. New York: Norton.

Erikson, E.H. (1959). Identity and the life cycle. Psychological Issues, 1 .

Fairbaim, W.R.D. (1952). An object-relations theory of the personality. New York: Basic Books.

Fenichel, O. (1945). The pychoanalytic theory of neurosis. New York: Norton.

Flax, J. (1978). The conflict between nurturance and autonomy in mother/daughter relationships and within feminism. Feminist Studies, 4, 71-89.

Gagnon, J., and Simon, W. (1968). Sexual Deviance in Contemporary America. Annals of the American Academy of political and Social Science, 376, 106-122.

Gilligan, C. (1982). In a different voice: Psychological theory and women's development. Cambridge: Harvard University Press.

Greenburg, J.R., Mitchell, S.A. (1983). Alternatives. In, Object relations in psychoanalytic theory (pp. 119-230). Cambridge: Harvard University Press.

Heilbrun, A.B., Jr., and Thompson, N.L. (1977). Sex Role Identity and Male and Female Homosexuality. Sex Roles, $\underline{3}$, 65-79.

Hirschfeld, R.M.A., Klerman, G.I., Gough, H.G., Barrett, J., Korchin, S.J., \& Chodoff, P. (1977). A measure of interpersonal dependency. Journal of Personality Assessment, 41, 610-618.

Jacobson, E. (1964). The self and the object world. New York: International Universities Press.

Jordan, J.V. (1984). Empathy and self boundaries. Work in Progress). Wellesley Massachusetts: Stone center Working Papers Series.

Karpel, M. (1976). Individuation: From fusion to dialogue. Family Process, 15, 65-82. 
Kernberg, 0. (1976). Object relations theory and clinical psychoanalysis. New York: Jason Aronson.

Kohut, H. (1977). The restoration of the self. New York: Intermational Universities Press.

Krestan, J., \& Bepko, C.S. (1980). The problem of fusion in the lesbian relationship. Family Process, 19, 277-281.

Kurdek, L.A., \& Schmitt, J.P. (1986a). Interaction of sex role self-concept with relationship quality and relationship beliefs in married, heterosexual, cohabiting, gay, and lesbian couples. Journal of Personality and Social Psychology, 51 (2), 365-370.

Kurdek, L.A., \& Schmitt, J.P. (1986b). Relationship quality of partners in heterosexual married, heterosexual cohabiting, and gay and lesbian relationships. Joumal of Personality and Social Psychology, 51 (4), 711-720.

Mahler, M. (1974). The selected papers of Margaret S. Mahler. New York: Jason Aronson.

Mendola, M. (1980). The Mendola Report: A New Look at Gay Couples. New York: Crown.

Morin, S.F. (1977). Heterosexual bias in psychological research on lesbianism and male homosexuality. American Psychologist, 32, 629-637.

Pearlin, L.I. (1971). Class Context and Family Relations; A Cross National Study. Boston: Little Brown.

Peplau, L.A., \& Cochran, S.D. (1981). Value orientations in the intimate relationships of gay men. Journal of Homosexuality, 6 (3), 1-9.

Peplau, L.A., Cochran, S., Rook, K., \& Podesky, C. (1978). Loving women: attachment and autonomy in lesbian relationships. Joumal of Social Issues, 34 (3), 7-27.

Riddle, D.I., \& Sang, B. (1978). Psychotherapy with lesbians. Journal of Social Issues, 34 (3), 84-100.

Rubin, L. (1983). Intimate Strangers. New York: Harper and Row.

Schneider, M.S., (1986). The relationships of cohabiting lesbians and heterosexual couples: A comparison. Psychology of Women Quarterly, 10, 234-239.

Schullo, S.A., \& Alperson B.I. (1984). Interpersonal phenomenology as a function of sexual orientation, sex, sentiment, and trait categories in long-term dyadic relationships. Journal of Personality and Social Psychology, 47 (5), 983-1002. 
Spence, J.T., \& Helmreich, R.L. (1978). Masculinity and femininity: Their psychological dimensions, correlates and antecedents. Austin: University of Texas Press.

Spence, J.T., \& Helmreich, R.L. (1980). Masculine instrumentality and feminine expressiveness: Their relationships with sex role attitudes and behaviors. Psychology of Women quarterly, 5 (2), 147-163.

Spence, J.T., Helmreich, R.L., \& Holahan, C.K. (1979). Negative and positive components of psychological masculinity and femininity and their relationships to self-reports of neurotic and acting out behaviors. Journal of Personality and Social Psychology, 37, 1673-1682.

Spence, J.T., \& Helmreich, R., \& Stapp, J. (1975). Ratings of self and peers on sex role attributes and their relation to self-esteem and conceptions of masculinity and femininity. Journal of Personality an Social Psychology, 32, 29-39.

Stern, D.N. (1983). The interpersonal world of the infant. New York: Basic Book.

Tan, A.L., Kendis, R.J., Fine, J.T., \& Porac, J. (1977). A short measure of ego identity. Journal of Personality Assessment, 41 (3), 279-284.

Veroff, J., Kulka, R., and Douvan, E. (1981). Mental Health In America: Patterns of Help Seeking. New York: Basic Books. 
APPENDIX A

NEWSIETTER ANNOUNCEMENT 


\section{NEWSLETTER ANNOUNCEMENT}

I am recruiting subjects for a graduate research project in psychology. Lesbian couples who have been in a relationship for one year or longer are needed.

The study consists of a questionnaire packet which can be filled out at your convenience and mailed to me. Results will be strictly confidential and subjects will remain anonymous.

I want you to know what the study is not about as well as what the study is about. It is not about why women become lesbians and; the study is not about how our relationships compare to other kinds of relationships.

The study is about how the closeness of lesbian relationships can be both good for the relationship and the individual and potentially difficult for the relationship and the individual.

The study seeks useful information to help our relationships thrive and our personal potentials to be reached.

If you and your partner would be interested in participating in my study please call me. 
APPENDIX B

BACKGROUND INFORMATION 
BACKGROUND INFORMATION

1. In what month and year were you born?

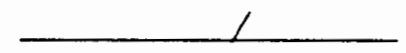

Month / Year

2. Which of the following describes your racial background? (check one)

White

Black

Hispanic

American Indian or Alaskan Native

Asian or Pacific Islander

Other (please describe:

3. What is your current employment status?

(check one)

Working Now

Permanently Disabled

Temporarily Laid-off

Unemployed

Retired

Student

4. What was your total income from all sources last year? 
5. How many years of education do you have?

(check highest level)

Grade School

College

Graduate School

Total number of years

6. What is your current religious preference?

(check one)

Jewish

Roman Catholic

Orthodox (Eastern, Greek or Russian)

Protestant

Islamic or Muslim

None

other (please specify:

7. How long have you been in your current relationship? years and months

8. How many lesbian relationships of one year or longer duration, have you had in the past?

9. Do you own your own home? (check one)

Yes

Yes, co-own

No 
10a. Are there children in your current household?

(check one)

Yes, full time

Yes, part time

No

10b. If yes, how many children?

10c. Who is the natural mother?

Yourself

Your partner

Adopted

11. What is today's date?
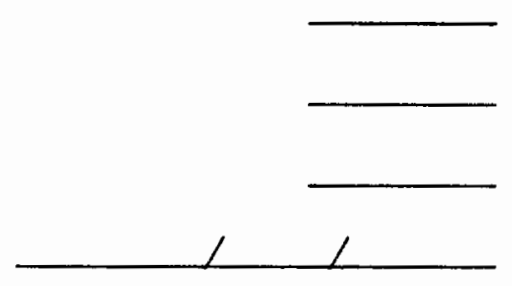

Month / Day / Year 
APPENDIX C

EXTENDED PERSONAL ATTRIBUTES QUESTIONNAIRE (EPAQ) 


\section{EXIENDED PERSONAL ATIRIBUTES QUESTIONNATRE (EPAQ)}

The following statements inquire about what kind of person you think you are. For each item, indicate how characteristic it is of you by choosing from the scale at the top of the page the appropriate letter on the scale, A, B, C, D, or E. "A" should be chosen if the statement is very characteristic of you and " $\mathrm{E}$ " if the item is not at all characteristic of you. B, C, or D should be chosen if the item is fairly, slightly, or not very characteristic of you. When you have decided on your answer, fill in the letter on the answer sheet next to the item number. The scale will appear at the top of each page.

\section{A}

very much

characteristic

of me
B fairly slightly
D

not very $E$

not at all characteristic of me

$M-F^{*}$ 1. I am a very forceful, "take charge" kind of person.

Fva- 2. When things go wrong, I get upset and whiny.

M+ 3. I am able to do tough things by myself if I have to. I don't need other people to help me or tell me what to do.

M- 4. I feel that "I'm the greatest" and better than other people.

F+ 5. I am very emotional. (That means my feelings get stirred up easily.)

$M-F$ 6. I give in to other people easily. I let them tell me what to do.

M- 7. I brag a lot about myself and what I do. 
$M-F \quad 8$. I get very upset and excited when big things go wrong.

M+ 9. I am very busy and active.

M- 10. I am a self-centered person. I want things to go my way.

F+ 11. I really like to do things for other people.

FC- 12. I haven't got a lot of nerve and have trouble standing up for myself.

F+ 13. I am NOT very gentle.

Fva- 14. I complain a lot about things not going right.

F+ 15. I am very helpful to other people.

M+ 16. I enjoy trying to win games and contests.

Fc- 17. I stay in the background and let other people tell me what to do.

M-F 18. I am a very loud person.

M- 19. I am a greedy person.

Ft 20. I am Nor very kind to other people.

M-F 21. It's very important to me that people like me and approve of the things I do.

M- 22. I am a bossy person.

M-F 23. My feelings are NOT hurt easily.

Fva- 24. I nag people a lot to get them to do things.

Ft 25. I don't pay much attention to how other people are feeling.

Mt 26. When I have to decide about something important, it's hard for me to make up my mind.

Fva- 27. I am a fussy person. I am easily annoyed and irritated.

M+ 28. I give up very easily.

M- 29. Most people only care about themselves. I don't trust them very much. 
M-F 30. I hardly ever cry.

M+ 31. I feel sure I can do most of the things I try.

M- 32. I remind myself that I'm "number one" and have to look out for myself first.

M+ 33. I am better at doing most things than other people.

M- 34. Lots of times people are out to do me wrong and I try to pay them back.

F+ 35. I try to understand how other people are feeling.

F+ 36. I am a very warm, friendly person.

Fc- 37. I try to please people and make them like me by giving in to them.

M-F 38. I like to play things safe. I do not take chances.

Fc- 39. I am very trustful of people. It's easy for them to fool me.

M+ 40. When I'm in a tough spot, I get very bothered and don't know what to do.

* M-F, M+, F+, FC-, Fva-, M- are the sex role trait categories indicated by the statement. This notation does not appear on the questionnaires sent to the respondents. 
APPENDIX D

EGO IDENTTTY SCALE (EIS) 
EGO IDENIITY SCALE (EIS)

Below are some pairs of statements. Please circle the letter of the statement in each pair that you agree with more. Please respond to every question.

1. a. I enjoy being active in clubs and youth groups.

b. I prefer to focus on hobbies which I can do on my own time, at my own pace.

2. a. When I daydream, it is primarily about my past experiences.

b. When I daydream, it is primarily about the future and what it has in store for me.

3. a. No matter how well I do a job, I always end up thinking I could have done better.

b. Whenever I complete a job that I have seriously worked, on, I usually do not have doubts as to its quality.

4. a. I will generally voice an opinion, even if I appear to be the only one in a group with that point of view.

b. If I appear to be the only one in a group with a certain opinion, I try to keep quiet in order to avoid feeling self-conscious.

5. a. Generally speaking, a person can keep much better control of himself and of situations if he maintains an emotional distance from others.

b. A person need not fear loss of control, of himself and of situations, simply because he becomes intimately involved with another person.

6. a. I have doubts as to the kind of person my abilities will enable me to become. 
b. I try to formulate ideas now which will help me achieve my future goals.

7. a. My evaluation of self-worth depends on the success or failure of my behavior in a given situation.

b. My self evaluation, while flexible, remains about the same in most situations.

8. a. While there may be disadvantages to competition, I agree that it is sometimes necessary and even good.

b. I do not enjoy competition, and often do not see the need for it.

9. a. There are times when I don't know what is expected of me.

b. I have a clear vision of how my life will unfold ahead of me.

10. a. What I demand of myself and what others demand of me are often in conflict.

b. Most of the time, I don't mind doing what others demand of me because they are things I would probably have done anyway.

11. a. When confronted with a task that I do not particularly enjoy, I find that I usually can discipline myself enough to perform them.

b. Often, when confronted with a task, I find myself expending my energies on other interesting but unrelated activities instead of concentrating on completing the task.

12. a. Because of my philosophy of life, I have faith in myself, and in society in general.

b. Because of the uncertain nature of the individual and society, it is natural for me not to have a basic trust in society, in others, or even in myself. 
APPENDIX E

INIERPERSONAL DEPENDENCY INVENTORY (IDI) 


\section{INIERPERSONAL DEPENDENCX INVENTORY (IDI)}

Instructions: 48 statements are presented below. Please read each one and decide whether or not it is characteristic of your attitudes, feelings, or behavior. Then assign a rating to every statement, using the values given below:

$$
\begin{aligned}
& 4 \text { = very characteristic of me } \\
& 3 \text { = quite characteristic of me } \\
& 2=\text { somewhat characteristic of me } \\
& 1=\text { not characteristic of me }
\end{aligned}
$$

1. I prefer to be by myself.

2. When I have a decision to make, I always ask for advice.

3. I do my best work when I know it will be appreciated.

4. I can't stand being fussed over when I am sick.

5. I would rather be a follower than a leader.

6. I believe people could do a lot more for me if they wanted to.

7. As a child, pleasing my parents was very important to me.

8. I don't need other people to make me feel good.

9. Disapproval by someone I care about is very painful for me.

10. I feel confident of my ability to deal with most of the personal problems I am likely to meet in life.

1I. I'm the only person I want to please.

12. The idea of losing a close friend is terrifying to me.

13. I am quick to agree with the opinions expressed by others. 
14. I rely only on myself.

15. I would be completely lost if I didn't have someone special.

16. I get upset when someone discovers a mistake I've made.

17. It is hard for me to ask someone for a favor.

18. I hate it when people offer me sympathy.

19. I easily get discouraged when I don't get what I need from others.

20. In an argument, I give in easily.

21. I don't need much from people.

22. I must have one person who is very special to me.

23. When I go to a party, I expect that the other people will like me.

24. I feel better when I know someone else is in cormand.

25. When I am sick, I prefer that my friends leave me alone.

26. I'm never happier than when people say I've done a good job.

27. It is hard for me to make up my mind about a TV show or movie until I know what other people think.

28. I am willing to disregard other people's feelings in order to accomplish something that's important to me.

29. I need to have one person who puts me above all others.

30. In social situations I tend to be very self-conscious.

31. I don't need anyone.

32. I have a lot of trouble making decisions by myself.

33. I tend to imagine the worst if a loved one doesn't arrive when expected. 
34. Even when things go wrong I can get along without asking for help from my friends.

35. I tend to expect too much from others.

36. I don't like to bury clothes by myself.

37. I tend to be a loner.

38. I feel that I never really get all that I need from people.

39. When I meet new people, I'm afraid that I won't do the right thing.

40. Even if most people turned against me, I could still go on if someone I love stood by me.

41. I would rather stay free of involvement with others than to risk disappointments.

42. What people think of me doesn't affect how I feel.

43. I think that most people don't realize how easily they can hurt me.

44. I am very confident about my own judgment.

45. I have always had a terrible fear that I will lose the love and support of people I desperately need.

46. I don't have what it takes to be a good leader.

47. I would feel helpless if deserted by someone I love. 48. What other people say doesn't bother me. 